\title{
Corrosion Inhibition of Carbon Steel in HCl Solution by Some Plant Extracts
}

\author{
Ambrish Singh, ${ }^{1}$ Eno E. Ebenso, ${ }^{2}$ and M. A. Quraishi ${ }^{1}$ \\ ${ }^{1}$ Department of Applied Chemistry, Institute of Technology, Banaras Hindu University, Varanasi 221005, India \\ ${ }^{2}$ Department of Chemistry, Faculty of Agriculture, Science \& Technology, North West University (Mafikeng Campus), \\ Mmabatho 2735, South Africa \\ Correspondence should be addressed to M. A. Quraishi, maquraishi.apc@itbhu.ac.in
}

Received 30 July 2011; Revised 13 October 2011; Accepted 17 October 2011

Academic Editor: Peter C. Okafor

Copyright () 2012 Ambrish Singh et al. This is an open access article distributed under the Creative Commons Attribution License, which permits unrestricted use, distribution, and reproduction in any medium, provided the original work is properly cited.

The strict environmental legislations and increasing ecological awareness among scientists have led to the development of "green" alternatives to mitigate corrosion. In the present work, literature on green corrosion inhibitors has been reviewed, and the salient features of our work on green corrosion inhibitors have been highlighted. Among the studied leaves, extract Andrographis paniculata showed better inhibition performance (98\%) than the other leaves extract. Strychnos nuxvomica showed better inhibition (98\%) than the other seed extracts. Moringa oleifera is reflected as a good corrosion inhibitor of mild steel in $1 \mathrm{M} \mathrm{HCl}$ with $98 \%$ inhibition efficiency among the studied fruits extract. Bacopa monnieri showed its maximum inhibition performance to be $95 \%$ at $600 \mathrm{ppm}$ among the investigated stem extracts. All the reported plant extracts were found to inhibit the corrosion of mild steel in acid media.

\section{Introduction}

Among the several methods of corrosion control and prevention, the use of corrosion inhibitors is very popular. Corrosion inhibitors are substances which when added in small concentrations to corrosive media decrease or prevent the reaction of the metal with the media. Inhibitors are added to many systems, namely, cooling systems, refinery units, chemicals, oil and gas production units, boiler, and so forth. Most of the effective inhibitors are used to contain heteroatom such as $\mathrm{O}, \mathrm{N}$, and $\mathrm{S}$ and multiple bonds in their molecules through which they are adsorbed on the metal surface. It has been observed that adsorption depends mainly on certain physicochemical properties of the inhibitor group, such as functional groups, electron density at the donor atom, $\pi$-orbital character, and the electronic structure of the molecule. Though many synthetic compounds showed good anticorrosive activity, most of them are highly toxic to both human beings and environment. The use of chemical inhibitors has been limited because of the environmental threat, recently, due to environmental regulations. These inhibitors may cause reversible (temporary) or irreversible (permanent) damage to organ system, namely, kidneys or liver, or disturbing a biochemical process or disturbing an enzyme system at some site in the body. The toxicity may be manifest either during the synthesis of the compound or during its applications. These known hazardous effects of most synthetic corrosion inhibitors are the motivation for the use of some natural products as corrosion inhibitors. Plant extracts have become important because they are environmentally acceptable, inexpensive, readily available and renewable sources of materials, and ecologically acceptable. Plant products are organic in nature, and some of the constituents including tannins, organic and amino acids, alkaloids, and pigments are known to exhibit inhibiting action. Moreover, they can be extracted by simple procedures with low cost. In the present work, the authors have reviewed literature on green corrosion inhibitors. Many authors such as E. E. Ebenso, B. Hammouti, A. Y. El Etre, P. C. Okafor, E. Oguzie, and P. B. Raja, have contributed significantly to the green mitigation by investigating several plants and their different body parts as corrosion inhibitors. The reviews of the literature along with salient features are summarised in Table 1.

In a previous work, the authors have investigated the extract of plants, namely, Azadirachta indica (leaves), Punica 
TABLE 1: Plant extracts investigated as corrosion inhibitors by other authors.

S. no. Inhibitors used Active constituents
Inhibition efficiency

$(\%)$<smiles>O=C1C=C(O)C(=O)c2ccccc21</smiles>

The aqueous extract of the leaves of henna (lawsonia) as the corrosion inhibitor was reported in $\mathrm{C}$ steel, nickel and zinc in acidic, neutral and alkaline solutions, using the polarization technique [1]<smiles>C[N+](C)(C)CCO</smiles>

Choline

The temperature effects were investigated on mild steel corrosion in $2.0 \mathrm{M}$ of $\mathrm{HCl}$ and<smiles>CSCCC(N)C(=O)O</smiles>
$\mathrm{H}_{2} \mathrm{SO}_{4}$ in the absence and presence of aqueous extract of fenugreek leaves (AEFLs) with the help of gravimetric method [2]

Methionine<smiles>CC=C1C(OC(C)C)OC=C(C(C)=O)C1CC(=O)[O-]</smiles>

(3)

Olea europaea

Oleuropein

93.0<smiles>OCCc1ccc(O)c(O)c1</smiles>

Hydroxytyrosol
The inhibitive action of the aqueous extract of olive leaves was reported towards the corrosion of $\mathrm{C}$-steel in $2 \mathrm{M} \mathrm{HCl}$ solution using weight loss measurements, Tafel polarization, and cyclic voltammetry [3]
Cotula cinerea, (4) Retama retam, and Artemisia herba
Plant extracts were investigated on the corrosion of X52 mild steel in aqueous 20\% (2.3 M) sulphuric acid. Weight loss determinations and electrochemical measurements were also performed [4] 
TABle 1: Continued.

\begin{tabular}{|c|c|c|c|c|}
\hline S. no. & Inhibitors used & Active constituents & $\begin{array}{c}\text { Inhibition efficiency } \\
(\%)\end{array}$ & Remarks \\
\hline (5) & Eclipta alba & $\mathrm{HO}$ & 99.6 & $\begin{array}{l}\text { The inhibition effect of Eclipta } \\
\text { alba in } 1 \mathrm{~N} \text { hydrochloric acid on } \\
\text { corrosion of mild steel was } \\
\text { investigated by weight loss, } \\
\text { potentiodynamic polarization, } \\
\text { and impedance methods, and the } \\
\text { extracts of Eclipta alba were found } \\
\text { to be effective corrosion pickling } \\
\text { inhibitor [5] }\end{array}$ \\
\hline (6) & $\begin{array}{l}\text { Rauvolfia } \\
\text { serpentina }\end{array}$ & $\begin{array}{l}\text { Reserpine, ajmalicine, ajmaline, isoajmaline, } \\
\text { ajmalinine, chandrine }\end{array}$ & 94.0 & $\begin{array}{l}\text { Rauvolfia serpentina was tested as } \\
\text { the corrosion inhibitor for mild } \\
\text { steel in } 1 \mathrm{M} \mathrm{HCl} \text { and } \mathrm{H}_{2} \mathrm{SO}_{4} \text { using } \\
\text { weight loss method at three } \\
\text { different temperatures, namely, } \\
303,313 \text {, and } 323 \mathrm{~K} \text {. } \\
\text { Potentiodynamic polarization, } \\
\text { electrochemical impedance } \\
\text { spectroscopy, and scanning } \\
\text { electron microscope (SEM) } \\
\text { studies were also performed [4] }\end{array}$ \\
\hline
\end{tabular}

Lupinus albus<smiles>C1CCN2CC3CC(CN4CCCCC34)C2C1</smiles>

Sparteine<smiles>O=C1CCCC2C3CC(CN12)C1CCCCN1C3</smiles>

Lupanine<smiles>O=C1C=CN2CC3CC(CN4CCCCC34)C2C1</smiles>

The behaviour of the inhibitive effect of lupine (Lupinus albus L.) extract on the corrosion of steel in aqueous solution of $1 \mathrm{M}$ sulphuric, and $2 \mathrm{M}$ hydrochloric acid was studied by potentiodynamic polarization and electrochemical impedance spectroscopy (EIS) techniques [6]
(8)

Solanum tuberosum

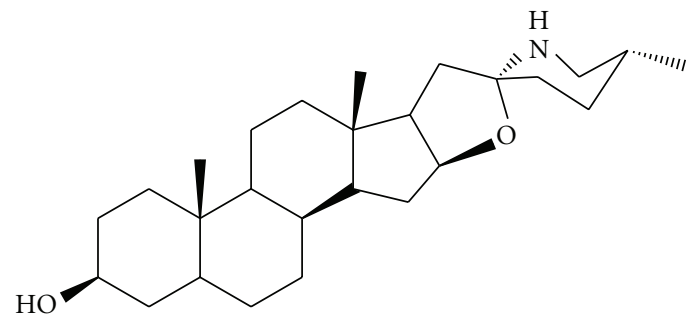

The acid extracts of Solanum tuberosum were studied as the corrosion inhibitor for mild steel 91.3 in $1 \mathrm{M} \mathrm{HCl}$ and $\mathrm{H}_{2} \mathrm{SO}_{4}$ medium using different techniques. It was found to be a good corrosion inhibitor [7]

Solasodine

Nauclea latifolia
Monoterpene, triterpene indole alkaloid, saponins
The inhibitive action of ethanol extracts from leaves (LV), bark (BK), and roots (RT) of Nauclea latifolia on mild steel corrosion in $\mathrm{H}_{2} \mathrm{SO}_{4}$ solutions at $30^{\circ}$ and $60^{\circ} \mathrm{C}$ was studied using weight loss and gasometric techniques [8] 
TABle 1: Continued.

S. no. Inhibitors used
Active constituents
Inhibition efficiency (\%)<smiles>CN[C@H](C)[C@H](O)c1ccccc1</smiles>

Ephedrine<smiles>COc1cc2c(cc1C)-c1cc3ccc(O)c(O)c3cc1CC2</smiles>

The efficacy of an acid extracts of leaves of Sida rhombifolia L. as the corrosion inhibitor for mild steel in $1 \mathrm{M}$ phosphoric acid medium using weight loss measurements, polarization, and electrochemical impedance spectral studies were investigated. It was found to be an effective corrosion inhibitor [9]
(11) Ammi visnaga

Khellin<smiles>COc1c2c(c(OC)c3c(=O)cc(C)oc13)CC=C2</smiles><smiles>COc1c2ccoc2cc2oc(C)cc(=O)c12</smiles>

Extracts were used in 5\% (w/v) commercial hydrochloric acid as corrosion inhibitors of mild steel exposed into $5 \%(\mathrm{w} / \mathrm{v})$

Embilica

uflicianalis,

Terminalia

chebula and

Terminalia

Emblicanin A\&B, puniglucanin, pedunculagin, tannic acid, chebulinic acid, and gallic acid

bellirica hydrochloric acid at $328 \mathrm{~K}$ on mild steel. Both Tafel polarization and linear polarization resistance techniques were used. Remarkable decrease in corrosion current and
The inhibitive effect of the extract of Khillah (Ammi visnaga) seeds, on the corrosion of SX 316 steel in $\mathrm{HCl}$ solution using weight loss measurements as well as potentiostatic technique, was assessed. Negative values were calculated for the energy of adsorption indicating the spontaneity of the adsorption process [10] increase in linear polarization resistance values were observed in the presence of the acid extracts [11]

Carica papaya

(13)
Papain, carpaine, chymopapain, azadirachtin, salannin, gedunin, and azadirone
Extracts were used as corrosion inhibitors for corrosion of mild steel. The percentage inhibition of efficiency was found to increase with the increase in concentration of both inhibitors [12] 
Table 1: Continued.

\begin{tabular}{|c|c|c|c|c|}
\hline S. no. & Inhibitors used & Active constituents & $\begin{array}{l}\text { Inhibition efficiency } \\
(\%)\end{array}$ & Remarks \\
\hline (14) & $\begin{array}{l}\text { Mentha } \\
\text { pulegium }\end{array}$ & Pulegone & $80 \%$ & $\begin{array}{l}\text { Natural oil extracted from } \\
\text { pennyroyal mint (Mentha } \\
\text { pulegium, PM) was evaluated as } \\
\text { the corrosion inhibitor of steel in } \\
\text { molar hydrochloric using weight } \\
\text { loss measurements, } \\
\text { electrochemical polarisation, and } \\
\text { EIS methods. PM oil acted as an } \\
\text { efficient cathodic inhibitor [13] }\end{array}$ \\
\hline$(15)$ & $\begin{array}{l}\text { Zanthoxylum } \\
\text { alatum }\end{array}$ & Terpineol, isoxazolidine, and imidazolinedione & $85 \%$ & $\begin{array}{l}\text { The inhibition effect of } \\
\text { Zanthoxylum alatum plant } \\
\text { extracts on the corrosion of mild } \\
\text { steel in } 5 \% \text { and } 15 \% \text { aqueous } \\
\text { hydrochloric acid solution was } \\
\text { investigated by weight loss and } \\
\text { electrochemical impedance } \\
\text { spectroscopy (EIS) methods. The } \\
\text { effect of temperature on the } \\
\text { corrosion behaviour of mild steel } \\
\text { in } 5 \% \text { and } 15 \% \text { HCl with the } \\
\text { addition of plant extracts was } \\
\text { studied in the temperature range } \\
50-80^{\circ} \mathrm{C} \text {. Surface analysis (SEM, } \\
\text { XPS and FT-IR) was also carried } \\
\text { out to establish the corrosion } \\
\text { inhibitive property of this plant } \\
\text { extract in HCl solution [14] }\end{array}$ \\
\hline$(16)$ & $\begin{array}{l}\text { Thyme, } \\
\text { Coriander, } \\
\text { Hibiscus, Anis, } \\
\text { Black Cumin } \\
\text { and Garden } \\
\text { Cress. }\end{array}$ & $\begin{array}{c}\text { Thymol, malic acid, salicin, glutamic acid, leucine, and } \\
\text { methionine }\end{array}$ & $85 \%$ & $\begin{array}{l}\text { Electrochemical impedance } \\
\text { spectroscopy has been successfully } \\
\text { used to evaluate the performance } \\
\text { of these compounds. The ac } \\
\text { measurements showed that the } \\
\text { dissolution process is activation } \\
\text { controlled. Potentiodynamic } \\
\text { polarization curves indicate that } \\
\text { the studied compounds are } \\
\text { mixed-type inhibitors. Thyme, } \\
\text { which contained the powerful } \\
\text { antiseptic thymol as the active } \\
\text { ingredient, offers excellent } \\
\text { protection for steel surface [15] }\end{array}$ \\
\hline$(17)$ & $\begin{array}{l}\text { Phoenix } \\
\text { dactylifera, } \\
\text { Lawsonia } \\
\text { inermis, and } \\
\text { Zea mays }\end{array}$ & $\begin{array}{l}\text { Lawsone, esculetin, fraxetin, allantoin, sterols, and } \\
\text { hordenine }\end{array}$ & $90 \%$ & $\begin{array}{l}\text { Extracts were used as corrosion } \\
\text { inhibitors for steel, aluminum, } \\
\text { copper, and brass in acid chloride } \\
\text { and sodium hydroxide solutions } \\
\text { using weight loss, solution } \\
\text { analysis, and potential } \\
\text { measurements. Only, Phoenix } \\
\text { dactylifera, Lawsonia inermis } \\
\text { extracts were found highly } \\
\text { effective in reducing corrosion rate } \\
\text { of steel in acid chloride solutions } \\
\text { and aluminum in sodium } \\
\text { hydroxide solutions [16] }\end{array}$ \\
\hline$(18)$ & Datura metel & $\begin{array}{l}\text { Scopolamine, b-sitosterol, daturadiol, tropine, and } \\
\text { daturilin }\end{array}$ & $86 \%$ & $\begin{array}{l}\text { Acid extract of the D. metel was } \\
\text { studied for its corrosion inhibitive } \\
\text { effect by electrochemical and } \\
\text { weight loss methods. The results } \\
\text { of AC impedance and polarisation } \\
\text { studies correlate well with the } \\
\text { weight loss studies [17] }\end{array}$ \\
\hline
\end{tabular}


TABle 1: Continued.

\begin{tabular}{lll} 
S. no. Inhibitors used & Active constituents & $\begin{array}{c}\text { Inhibition efficiency } \\
(\%)\end{array}$ \\
\hline & Remarks
\end{tabular}

Mentha was used as the corrosion inhibitor of steel in molar hydrochloric using weight loss

(20) Mentha pulegium

Pugelone, alpha-pinene, limonene, methone, and piperitone

$80 \%$

Chymopapain, pectin, carposide, carpaine, pseudocarpaine, dehydrocarpines, carotenoids, cryptoglavine, cis-violaxanthin, and antheraxanthin.

(21) Carica papaya measurements, electrochemical polarisation and EIS methods. The increase in temperature leads to an increase in the inhibition efficiency of the natural substance [19]

Acid extracts of the different parts of Carica papaya were used as inhibitors in various corrosion tests. Gravimetric and gasometric techniques were used to characterize the mechanism of inhibition [20]

The inhibitive effect of the gum exudate from Acacia seyal var. seyal was studied on the corrosion of mild steel in drinking water using potentiodynamic polarization and electrochemical impedance spectroscopy (EIS) techniques. The corrosion rates of steel and inhibition efficiencies of the gum exudates obtained from impedance and polarization measurements were in good agreement [21]

Extract of the C. procera was studied for its corrosion inhibitive effect by weight loss, electrochemical, SEM, and UV methods. Using weight loss measurement data, mechanism of inhibitive action is probed by fitting in the adsorption isotherm [22]

Centella asiatica was studied as the corrosion inhibitor on mild steel in $1 \mathrm{~N}$ hydrochloric acid by weight loss method, gasometric method, potentiodynamic polarization method and AC impedance method [23] 
Table 1: Continued.

S. no. Inhibitors used $\quad$ Active constituents $\left.\quad \begin{array}{c}\text { Inhibition efficiency } \\ (\%)\end{array}\right)^{\text {Remarks }}$

Allium

sativum,

Juglans regia

and

Pogostemon

cablin
Allyl cysteine sulfoxide, methyl allyl thiosulfinate, allicin, diallyl disulfide, diallyl trisulfide, ajoene, pogostone, friedelin, epifriedelinol, pachypodol, retusine, and oleanolic acid
$94 \%$ steel in aqueous solution of I N sulphuric acid were studied by potentiodynamic polarization and electrochemical impedance spectroscopy (EIS) techniques [24]

Mature leaves of Combretum bracteosum were used for the corrosion inhibition of mild steel Combretum bracteosum

Tannic acid

$83 \%$ in $\mathrm{H}_{2} \mathrm{SO}_{4}$. Inhibition efficiency increases with the plant extracts concentration and decreases with temperature [25]

The inhibitive action of leaves (LV), seeds (SD), and a combination of leaves and seeds (LVSD) extracts of Phyllanthus amarus on mild steel corrosion in $\mathrm{HCl}$ and $\mathrm{H}_{2} \mathrm{SO}_{4}$ solutions was studied using weight loss and gasometric techniques. The results indicated that the extracts functioned as a good inhibitor in both environments and inhibition efficiency increased with extracts concentration. Temperature studies revealed an increase in inhibition efficiency with the rise in temperature, and activation energies decreased in the presence of the extract [26]

The inhibitive action of leaves (LV), root (RT), and seeds (SD) extracts of Azadirachta indica on mildsteel corrosion in $\mathrm{H}_{2} \mathrm{SO}_{4}$ solutions was studied using weight loss and gasometric techniques. The results obtained indicate that the extracts functioned as good inhibitors in $\mathrm{H}_{2} \mathrm{SO}_{4}$ solutions. Inhibition efficiency was found to increase with extracts concentration and temperature and followed the trend: $\mathrm{SD}>\mathrm{RT}>\mathrm{LV}$. A mechanism of chemical adsorption of the phytochemical components of the plant extracts on the surface of the metal is proposed for the inhibition behaviour. The experimental data fitted into the Freundlich adsorption isotherm [27] 
Table 1: Continued.

S. no. Inhibitors used
Active constituents
Inhibition efficiency

(\%)

Remarks

\section{Musa}

(29) sapientum and banana peels
Gallocatechin and dopamine

$71 \%$
Murraya
koenigii
$80 \%$

biotin, cytidine, inosine, guanine, guanosine, and
$90 \%$

Sativa

Medicago

Sativa

\begin{abstract}
riboflavin
\end{abstract}
The inhibition of the corrosion of mild steel by ethanol extract of Musa sapientum peels in $\mathrm{H}_{2} \mathrm{SO}_{4}$ was studied using gasometric and thermometric methods. The results of the study reveal that the different concentrations of ethanol extract of $M$. sapientum peels inhibit mild steel corrosion [28]

The inhibitive action of extract of curry leaves (Murraya koenigii) on carbon steel in $1 \mathrm{~N} \mathrm{HCl}$ was studied using weight loss, gasometric studies electrochemical polarization, and $\mathrm{AC}$ impedance measurements [29]

The inhibitive effect of water and alcoholic extracts of Medicago Sativa (MS) on the corrosion of steel in $2.0 \mathrm{M} \mathrm{H}_{2} \mathrm{SO}_{4}$ containing $10 \% \mathrm{EtOH}$ has been studied using chemical (weight loss (ML), hydrogen evolution (HE)), electrochemical (potentiodynamic polarization (PDP) and impedance spectroscopy (EIS)) techniques [30].

The inhibition effect of alkaloids extract from Oxandra asbeckii plant (OAPE) on the corrosion of C38 steel in $1 \mathrm{M}$ hydrochloric acid solution was investigated by potentiodynamic polarization and electrochemical impedance spectroscopy (EIS). The corrosion inhibition efficiency increases on increasing plant extracts concentration. Cathodic and anodic polarization curves showed that OAPE is a mixed-type inhibitor [31]

The inhibitive action of the extracts of Adhatoda vasica, Eclipta alba, and Centella asiatica on the corrosion of mild steel in $1 \mathrm{~N} \mathrm{HCl}$ was studied using weight loss
method, electrochemical methods, and hydrogen permeation method. Polarization method indicated that the plant extracts are under mixed control, that is, promoting retardation of both anodic and cathodic reactions [32] 
Table 1: Continued.

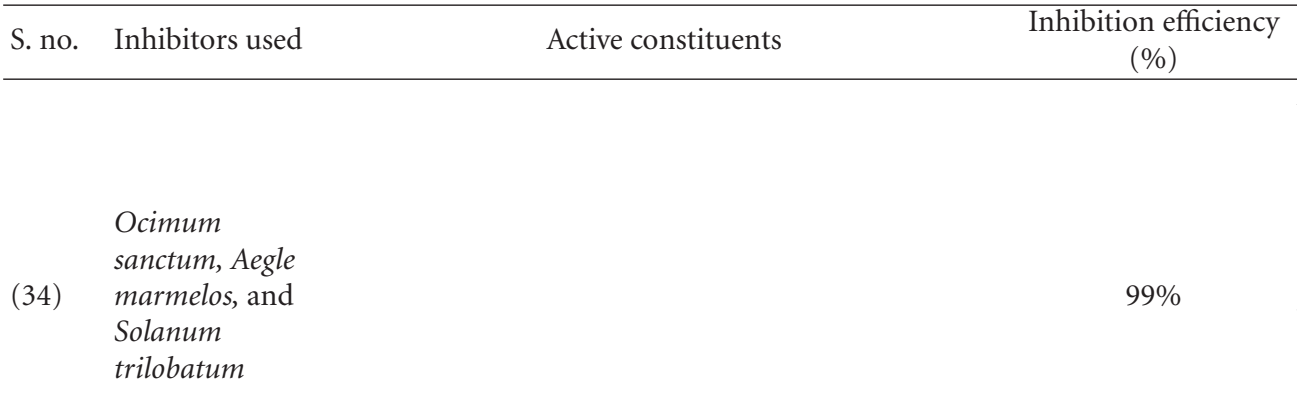

Remarks

A comparative study of the inhibitory effect of plant extracts, Ocimum sanctum, Aegle marmelos, and Solanum trilobatum, on the Corrosion of mild steel in $1 \mathrm{~N} \mathrm{HCl}$ medium was investigated using weight loss method, electrochemical methods, and hydrogen permeation method. Polarization method indicated that plant extracts behaved as mixed-type inhibitor [33]

Alkaloids extract from Annona squamosa plant has been studied as possible corrosion inhibitor for

C38 steel in molar hydrochloric
acid $(1 \mathrm{M} \mathrm{HCl})$. Potentiodynamic

Anna

squamosa

Liriodenine and oxoanalobine

$84 \%$
(36)

Heinsia crinita
(37)

Dacryodis

edulis polarization and $\mathrm{AC}$ impedance methods have been used. The corrosion inhibition efficiency increases on increasing plant extract concentration [34]

The paper provides information on the use of ethanol extract of Heinsia crinita as a corrosion inhibitor. Electrochemical studies such as polarisation and $\mathrm{AC}$ impedance spectra will throw more light on the mechanistic aspects of the corrosion inhibition [35]

The inhibition of low-carbon-steel corrosion in $1 \mathrm{M} \mathrm{HCl}$ and $0.5 \mathrm{M}$ $\mathrm{H}_{2} \mathrm{SO}_{4}$ by extracts of Dacryodis edulis (DE) was investigated using gravimetric and electrochemical techniques. DE extract was found to inhibit the uniform and localized corrosion of carbon steel in the acidic media, affecting both the cathodic and anodic partial reactions [36]

Corrosion inhibition efficiency of acid extract of dry Emblica officinalis leaves for mild steel in

Emblica

officinalis
$87 \%$

3-epikatonic acid 7-o-beta-(2-rhamnosyl-glucosyl)
Cyamopsis tetragonoloba myricetin, ash, astragalin, caffeic acid, and chlorogenic acid
$1 \mathrm{~N} \mathrm{HCl}$ medium was investigated. Experimental methods include weight loss, potentiodynamic polarization, and impedance studies [37]

The role of seed extract of Cyamopsis tetragonoloba on corrosion mitigation of mild steel in $1 \mathrm{M} \mathrm{HCl}$ was investigated by weight loss method and potentiodynamic polarization technique. Experimental results were fitted into Langmuir and Temkin adsorption isotherm to study the process of inhibition [38] 
granatum (shell), and Momordica charantia as corrosion inhibitors on mild steel in $3 \% \mathrm{NaCl}$ solution by chemical and electrochemical methods. Maximum inhibition efficiency of $86 \%, 82 \%$, and $79 \%$ was obtained at a concentration of $6 \mathrm{~mL} / \mathrm{L}, 3 \mathrm{~mL} / \mathrm{L}$ and $1.2 \mathrm{~mL} / \mathrm{L}$, respectively. Azadirachta indica showed $97 \%$ antiscaling properties [39].

Aqueous extracts of Cordia latifolia and Curcumin were investigated as corrosion inhibitors for mild steel in industrial cooling systems. The extracts showed maximum inhibition efficiency of $97.7 \%$ and $60 \%$, respectively [40].

The inhibitive effect of the aqueous extract of Jasmin (Jasminum auriculatum) on corrosion of mild steel in $3 \% \mathrm{NaCl}$ was investigated. It showed inhibition efficiency of $80 \%$. It was found to be predominantly the anodic corrosion inhibitor [41].

The inhibitive effects of aqueous extracts of Eucalyptus (leaves), Hibiscus (flower), and Agaricus on the corrosion of mild steel for cooling-water systems, using tap water, have been investigated by means of weight loss (under static as well as dynamic conditions) and polarization methods. All the plant extracts were found to inhibit corrosion of mild steel following and their inhibitive efficiencies were in the order: Agaricus (85\%), Hibiscus (79\%), and Eucalyptus (74\%) under the static test conditions. The inhibition efficiencies remain almost the same under the dynamic test conditions, which are nearer to field conditions. All the inhibitors (extracts) were found to follow Langmuir as well as Freundlich adsorption isotherms, that is, they inhibit corrosion through adsorption. Polarization measurements gave a similar order of inhibition efficiencies of plant extracts as that determined using the weight loss technique. Agaricus extract was found to be predominantly a cathodic inhibitor, while the extracts of Eucalyptus and Hibiscus were found to be mixed inhibitors [40].

Ascorbic acid in combination with DQ-2000 (aminotrimethyl phosphonic acid) and DQ-2010 (1-hydroxyethylidine 1,1-diphosphonic acid) was used to reduce the concentration of zinc in the blowdown of the cooling systems. All the inhibitors used were found to be effective. The maximum inhibition efficiency $99.2 \%$ was obtained with DQ-2010 $100 \mathrm{ppm}+$ Ascorbic acid $200 \mathrm{ppm}$ concentration. Inhibitors follow Langmuir isotherm which showed that they inhibit corrosion through adsorption [42].

In present work, authors have used the extract of (Kalmegh) Andrographis paniculata, (Meethi Neem) Murraya koenigii, (Bael) Aegle marmelos, (Kuchla) Strychnos nuxvomica, (Karanj) Pongamia pinnata, (Jamun) Syzygium cumini, (Shahjan) Moringa oleifera, (Pipali) Piper longum, (Orange) Citrus aurantium, (Brahmi) Bacopa monnieri, (Pipal) Ficus religiosa, and (Arjun) Terminalia arjuna as corrosion inhibitors [43-48]. The active constituents and inhibition efficiencies of the extracts used are summarized in Table 2.

\section{Experimental}

Prior to all measurements, the mild steel specimens, having composition (in wt\%) $0.076 \mathrm{C}, 0.012 \mathrm{P}, 0.026 \mathrm{Si}, 0.192$ Mn, $0.050 \mathrm{Cr}, 0.135 \mathrm{Cu}, 0.023 \mathrm{Al}, 0.050 \mathrm{Ni}$, and the remainder iron, were polished successively with fine grade Emery papers from 600 to 1200 grades. The specimens were washed thoroughly with double-distilled water and finally degreased with acetone and dried at room temperature. The aggressive solution $1 \mathrm{M} \mathrm{HCl}$ was prepared by dilution of analytical grade $\mathrm{HCl}(37 \%)$ with double-distilled water, and all experiments were carried out in unstirred solutions.

AC impedance (EIS) measurements and potentiodynamic polarization studies were carried out using a GAMRY PCI 4/300 electrochemical work station based on ESA 400. Gamry applications include EIS 300 (for EIS measurements) and DC 105 software (for corrosion) and Echem Analyst $(5.50 \mathrm{~V})$ software for data fitting. All electrochemical experiments were performed in a Gamry three-electrodes electrochemical cell under the atmospheric conditions with a platinum counter electrode and a saturated calomel electrode (SCE) as the reference electrode. The working electrode mild steel $\left(7.5 \mathrm{~cm}\right.$ long stem) with the exposed surface of $1.0 \mathrm{~cm}^{2}$ was immersed into aggressive solutions with and without inhibitor, and then the open circuit potential was measured after 30 minutes. EIS measurements were performed at corrosion potentials, $E_{\text {corr }}$, over a frequency range of $100 \mathrm{kHz}$ to $10 \mathrm{mHz}$ with an AC signal amplitude perturbation of $10 \mathrm{mV}$ peak to peak. Potentiodynamic polarization studies were performed with a scan rate of $1 \mathrm{mVs}^{-1}$ in the potential range from $250 \mathrm{mV}$ below the corrosion potential to $250 \mathrm{mV}$ above the corrosion potential. All potentials were recorded with respect to the SCE.

\section{Results and Discussion}

3.1. Leaves Extract as Corrosion Inhibitors. The leaves extract of Andrographis paniculata, Murraya koenigii, and Aegle marmelos were investigated as corrosion inhibitors by weight loss and electrochemical methods in the present study. Among the studied leaves extract, Andrographis paniculata showed better inhibition performance than the other leaves extract. The result is summarized in Table 3 and Figure 1. The order of their inhibition efficiency has been found as follows:

$$
\begin{aligned}
& \text { Andrographis paniculata } \\
& \quad>\text { Murraya koenigii }>\text { Aegle marmelos. }
\end{aligned}
$$

The higher inhibitive performance of Andrographis paniculata is due to the presence of delocalized $\pi$-electrons. This extensive delocalized $\pi$-electrons favours its greater adsorption on the mild steel surface, thereby giving rise in very high inhibition efficiency $(98.1 \%)$ at a concentration of $1200 \mathrm{ppm}$ the relatively better performance of Murraya koenigii (96.7\%) at $600 \mathrm{ppm}$ than Aegle marmelos (96.2\%) at $400 \mathrm{ppm}$. The most pronounced effect and the highest $R_{\mathrm{ct}}$ value $\left(491.0 \mathrm{ohm} \mathrm{\textrm {cm } ^ { 2 }}\right.$ ) was obtained by inhibitor Andrographis paniculata at $1200 \mathrm{ppm}$ concentration. The lowest $R_{\mathrm{ct}}$ value $\left(264.8 \mathrm{ohm} \mathrm{\textrm {cm } ^ { 2 }}\right)$ was obtained by inhibitor Aegle marmelos. The high $R_{\mathrm{ct}}$ values are generally associated with a slower corroding system. These data revealed that $R_{\mathrm{ct}}$ values increased after the addition of inhibitors, and on the other hand, $C_{\mathrm{dl}}$ values decreased. This situation was a result of the adsorption of inhibitors at the metal/solution interface. 
TABle 2: Plant extracts used by us as corrosion inhibitors.

\begin{tabular}{|c|c|c|c|c|}
\hline S. no. & Plant used & Active constituents & Common name & $\begin{array}{c}\text { Inhibition } \\
\text { efficiency }(\%)\end{array}$ \\
\hline (A) & Murraya koenigii & & & 96.7 \\
\hline (1) & & & Murrafoline-I & \\
\hline
\end{tabular}

(C) Andrographis<smiles>CC(C)=CCCC1(C)C=Cc2c3ccc(c2Nc2c-3cc(C)c(O)c2-c2cc3c(cc2O)[nH]c2c4c(c(C)cc23)OC(C)(CCC=C(C)C)C=C4)C=CO1</smiles>

Pyrayafoline-D

Mahabinine-A

(B) Aegle marmelos<smiles>COc1ccc2c(OC)c3ccoc3nc2c1OC</smiles><smiles>C=C1CC[C@H]2[C@@H](CO)[C@H](O)CC[C@]2(C)[C@H]1C/C=C1/C(=O)OC[C@H]1O</smiles><smiles>O=c1oc2c(O)c(O)cc3c(=O)oc4c(O)c(O)cc1c4c23</smiles> 
Table 2: Continued.

\begin{tabular}{|c|c|c|c|c|}
\hline S. no. & Plant used & Active constituents & Common name & $\begin{array}{l}\text { Inhibition } \\
\text { efficiency (\%) }\end{array}$ \\
\hline
\end{tabular}

(2)

(3)

(1)

(2)

(3)

(E)

Pongamia pinnata

1)<smiles>COc1c(-c2ccccc2)oc2c(ccc3occc32)c1=O</smiles><smiles>O=C(O)/C=C/c1ccc(O)c(O)c1</smiles><smiles>O=C(O)c1cc(O)c(O)c(O)c1</smiles>

Gallic acid

Quercetin

Cafeic acid<smiles>COc1c(-c2ccc3c(c2)OCO3)oc2c(ccc3occc32)c1=O</smiles><smiles>COc1cc2c(=O)cc(-c3ccccc3)oc2c2ccoc12</smiles><smiles>O=c1cc(-c2ccc(O)c(O)c2)oc2c1ccc1occc12</smiles>

(4)
97.6

Karanjin

Pongapine

Kanjone

Pongaglabrone 
Table 2: Continued.

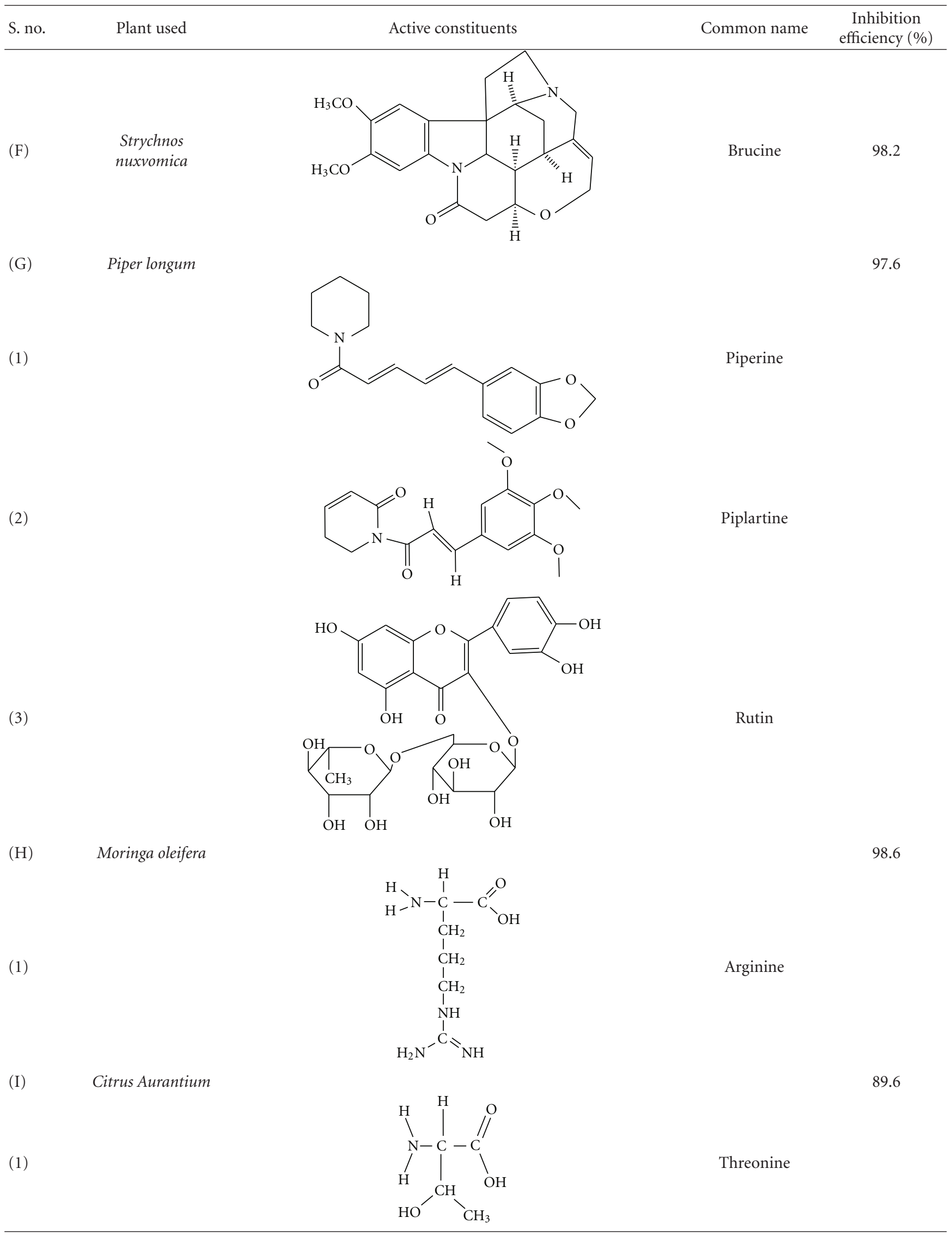


Table 2: Continued.

\begin{tabular}{|c|c|c|c|c|}
\hline S. no. & Plant used & Active constituents & Common name & $\begin{array}{c}\text { Inhibition } \\
\text { efficiency }(\%)\end{array}$ \\
\hline$(\mathrm{J})$ & Terminalia arjuna & & & 88.9 \\
\hline (1) & & & b-Sitosterol & \\
\hline$(\mathrm{K})$ & Ficus religiosa & & & 88.8 \\
\hline (1) & & & Lanosterol & \\
\hline (L) & Bacopa monnieri & & & 95.2 \\
\hline (1) & & & Bacoside A & \\
\hline (2) & & & Bacoside B & \\
\hline
\end{tabular}

A decrease in local dielectric constant and/or an increase in the thickness of the electrical double layer can cause this decrease in $C_{\mathrm{d} l}$ values, suggesting that the water molecules (having high dielectric constant) are replaced with inhibitor molecules (having low dielectric constant). It is worth noting that the percentage inhibition efficiencies obtained from impedance measurements were reasonably in a good agreement with those obtained from weight loss measurements.

3.2. Seed Extracts as Corrosion Inhibitors. We have used seed extracts of Strychnos nuxvomica, Pongamia pinnata, and Syzygium cumini in our present study. The result is concluded in Table 4 and Figure 2. The order of their inhibition efficiency has been found as follows:

$$
\begin{aligned}
& \text { Strychnos nuxvomica } \\
& \quad>\text { Pongamia pinnata }>\text { Syzygium cumini. }
\end{aligned}
$$

The best performance of Strychnos nuxvomica as the corrosion inhibitor can be attributed to the presence of three methoxy groups attached to the benzene nucleus. These extensive groups favor its greater adsorption on the mild steel surface, thereby giving rise to very high inhibition efficiency $(98.2 \%)$ at a concentration as low as $350 \mathrm{ppm}$. The next 
TABLE 3: Electrochemical impedance and Tafel data at $308 \mathrm{~K}$.

\begin{tabular}{|c|c|c|c|c|c|c|c|}
\hline Name of inhibitor & $\begin{array}{c}\text { Inhibitor } \\
\text { concentration }\end{array}$ & $R_{\mathrm{ct}}\left(\Omega \mathrm{cm}^{2}\right)$ & $C_{\mathrm{dl}}\left(\mu \mathrm{F} \mathrm{cm}^{-2}\right)$ & $E(\%)$ & $\begin{array}{c}-E_{\text {corr }} \\
(\mathrm{mV} \text { versus SCE })\end{array}$ & $i_{\text {corr }}\left(\mathrm{mA} / \mathrm{cm}^{2}\right)$ & $E(\%)$ \\
\hline $1 \mathrm{M} \mathrm{HCl}$ & - & 8.5 & 68.9 & - & 446 & 1540.0 & - \\
\hline \multirow{3}{*}{ Murraya koenigii } & 240.0 & 180.3 & 59.0 & 95.3 & 480 & 71.0 & 95.5 \\
\hline & 300.0 & 256.2 & 58.2 & 96.6 & 469 & 48.0 & 96.9 \\
\hline & 600.0 & 344.3 & 50.5 & 97.5 & 472 & 47.0 & 97.0 \\
\hline \multirow{3}{*}{ Aegle marmelos } & 200.0 & 101.9 & 59.2 & 91.7 & 457 & 159.0 & 89.3 \\
\hline & 300.0 & 151.1 & 44.1 & 94.4 & 466 & 100.0 & 93.5 \\
\hline & 400.0 & 264.8 & 30.7 & 96.7 & 499 & 60.0 & 96.0 \\
\hline \multirow{3}{*}{$\begin{array}{l}\text { Andrographis } \\
\text { paniculata }\end{array}$} & 300.0 & 99.0 & 56.9 & 91.4 & 489 & 82.0 & 94.6 \\
\hline & 600.0 & 108.0 & 52.4 & 92.1 & 462 & 59.0 & 96.1 \\
\hline & 1200.0 & 491.0 & 40.4 & 98.2 & 486 & 30.6 & 98.0 \\
\hline
\end{tabular}

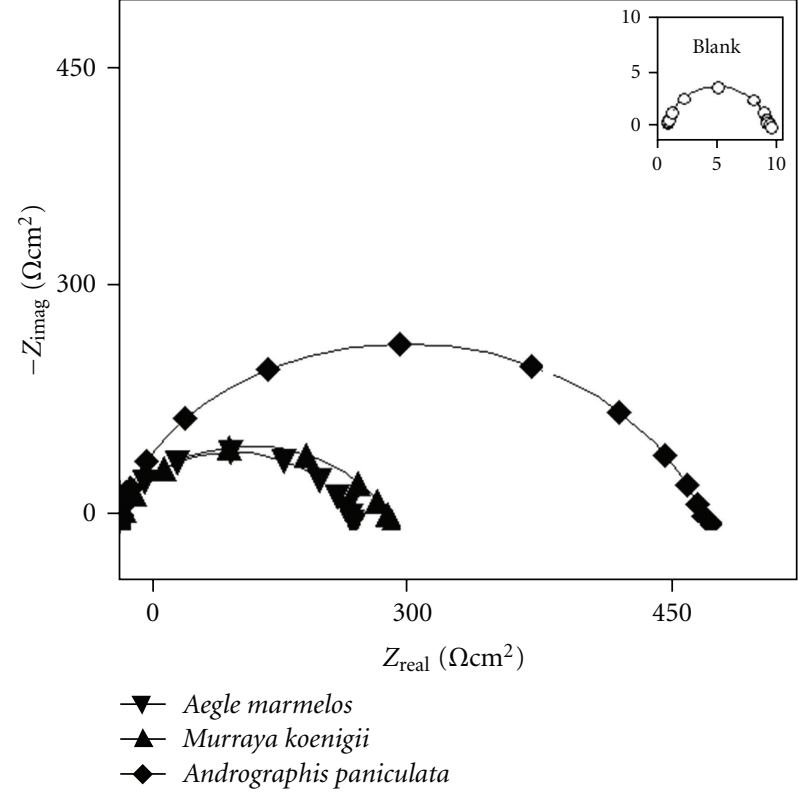

(a)

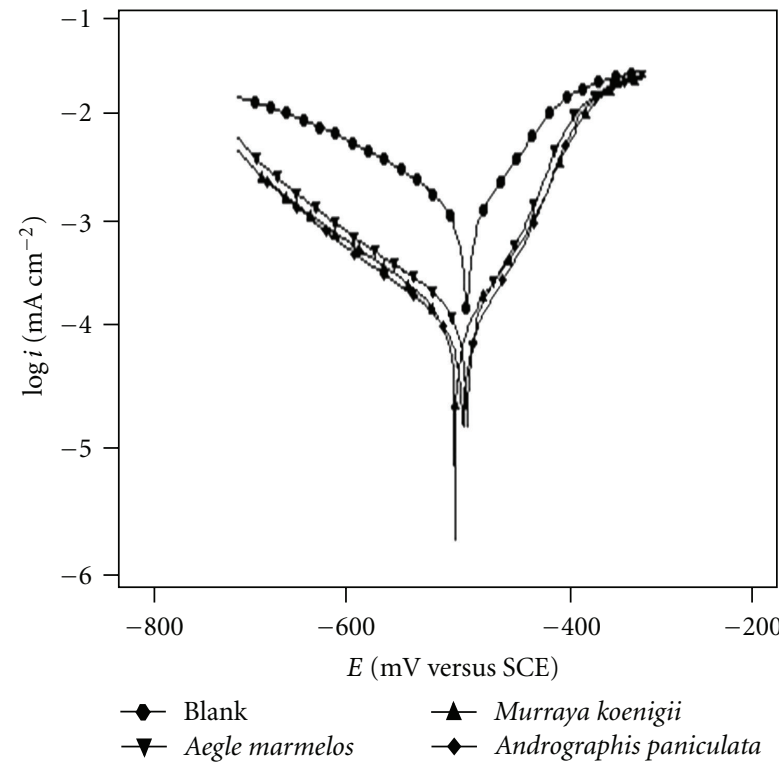

(b)

FIGURE 1: Nyquist plots and Tafel plots for mild steel in $1 \mathrm{M} \mathrm{HCl}$ in the absence and presence of different inhibitors at their optimum concentration.

best performance of Pongamia pinnata (97.6\%) has been found at $400 \mathrm{ppm}$ concentration. It was found that $R_{\mathrm{ct}}$ values increased to a maximum of $264\left(\Omega \mathrm{cm}^{2}\right)$ at an optimum concentration of Strychnos nuxvomica. This situation was a result of the adsorption of inhibitors at the metal/solution interface. In the present study, maximum displacement was $48 \mathrm{mV}$, suggesting that tested seeds extract belonged to the mixed-type inhibitors.

3.3. Fruits Extracts as Corrosion Inhibitors. We have used fruits extract of Moringa oleifera, Piper longum and Citrus aurantium in our present study. The result is depicted in Table 5 and Figure 3. The inhibition efficiency of fruits extract follows the order

$$
\begin{aligned}
& \text { Moringa oleifera } \\
& \quad>\text { Piper longum }>\text { Citrus aurantium }
\end{aligned}
$$

Good performance of fruits extract as corrosion inhibitors for mild steel in $1 \mathrm{M} \mathrm{HCl}$ solutions may be due to the presence of heteroatoms, $\pi$-electrons, and aromatic rings in their structures. The highest inhibition efficiency shown by Moringa oleifera is $98.2 \%$ at $300 \mathrm{ppm}$ due to the presence of imine $(\mathrm{C}=\mathrm{N})$ group, four $\mathrm{N}$ atoms, and long alkyl chain and least efficiency of Citrus aurantium is $88.1 \%$ at $1200 \mathrm{ppm}$ attributed to the presence of electron withdrawing $\mathrm{COOH}$ group. The $R_{\mathrm{ct}}$ values were found to increase, and on the other hand, $C_{\mathrm{dl}}$ values decreased in the presence of all fruits extract. This is due to the adsorption of these compounds at the metal/solution interface. The values of $I_{\text {corr }}$ were found to decrease in the presence of inhibitors. The decrease in $I_{\text {corr }}$ values can be due to the adsorption of fruits extract on the mild steel surface. It was observed that there is a small shift towards the cathodic region in the values of $E_{\text {corr. }}$ In 


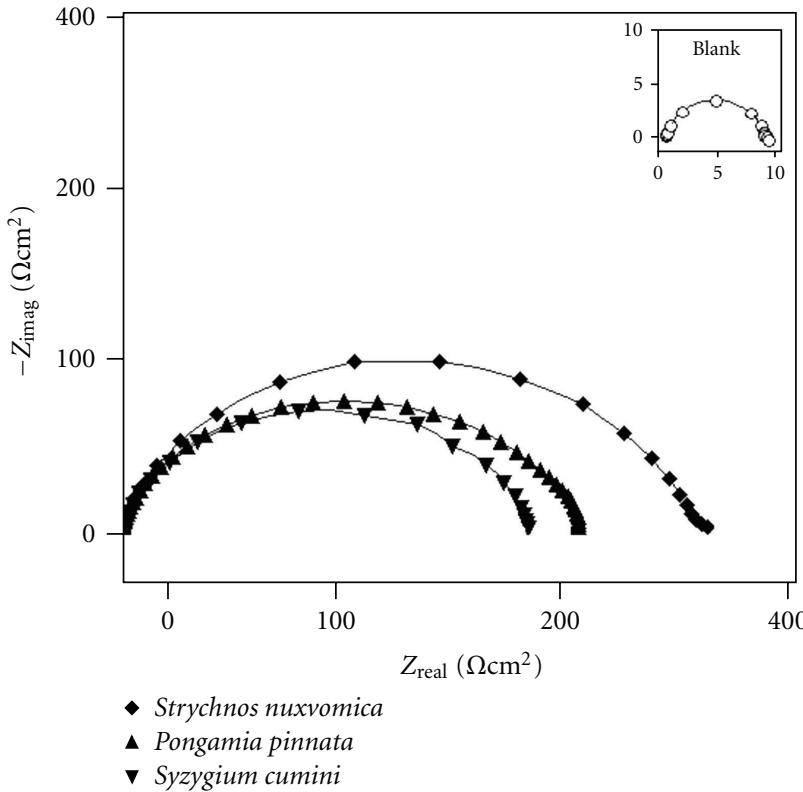

(a)

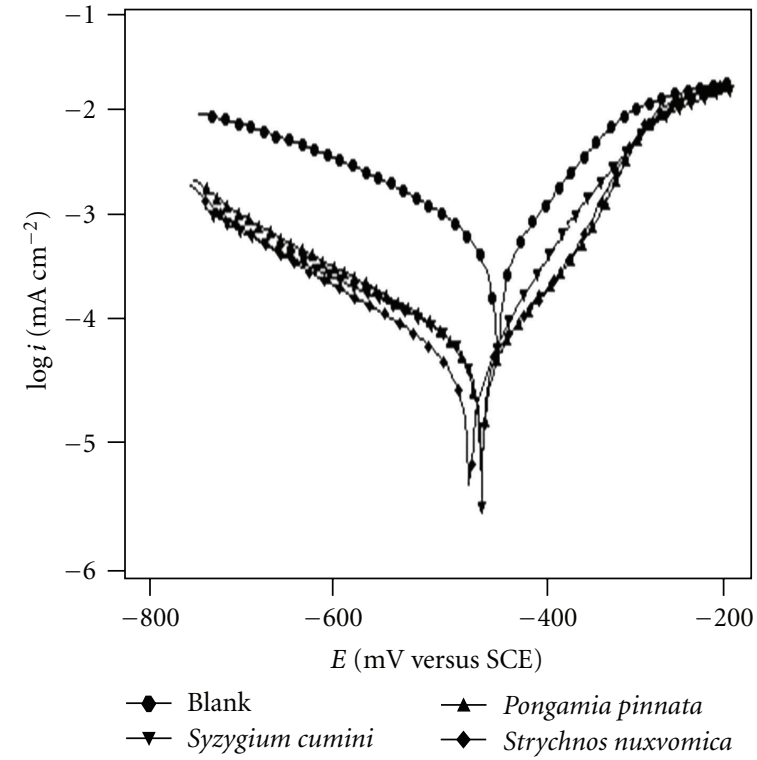

(b)

FIgURE 2: Nyquist plots and Tafel plots for mild steel in $1 \mathrm{M} \mathrm{HCl}$ in the absence and presence of different inhibitors at their optimum concentrations.

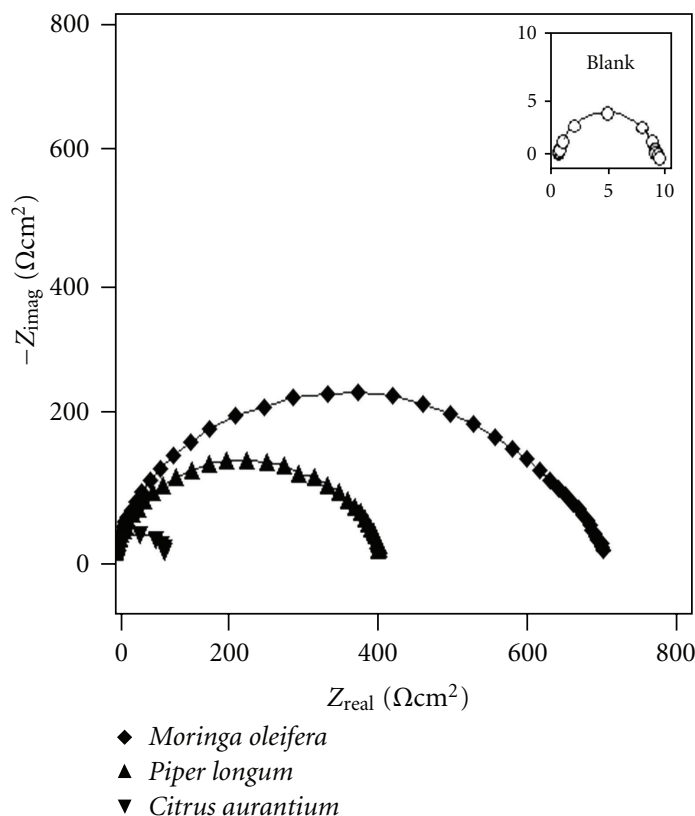

(a)

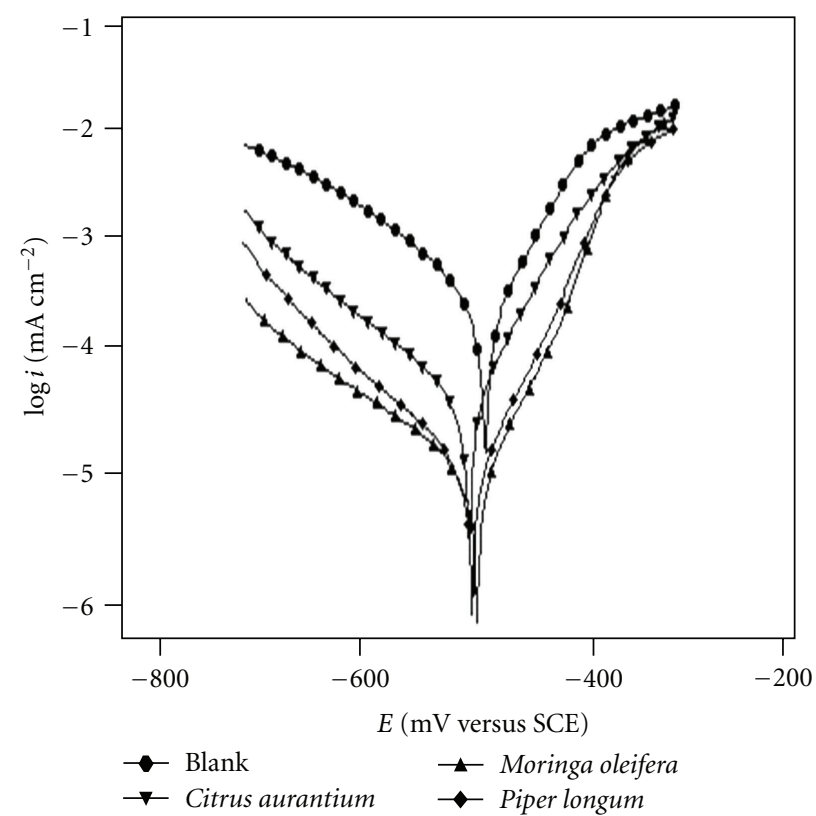

(b)

FIgure 3: Nyquist plots and Tafel plots for mild steel in $1 \mathrm{M} \mathrm{HCl}$ in the absence and presence of different inhibitors at their optimum concentrations.

the present study, maximum displacement in $E_{\text {corr }}$ value was $69 \mathrm{mV}$, which indicates that all studied fruits extract were mixed-type inhibitors.

3.4. Stem Extracts as Corrosion Inhibitors. Stem extracts of Bacopa monnieri, Ficus religiosa, and Terminalia arjuna were used as corrosion inhibitors. Bacopa monnieri showed its maximum inhibition performance $95.2 \%$ at $600 \mathrm{ppm}$, while Ficus religiosa shows $88.7 \%$ at $1200 \mathrm{ppm}$. The better performance of Bacopa monnieri can be attributed to the presence of more $\mathrm{O}$ atoms in its structure. Terminalia arjuna has been found to give its maximum inhibition efficiency $83.4 \%$ at $1200 \mathrm{ppm}$. The $R_{\mathrm{ct}}$ values were found to increase and on the other hand, $C_{\mathrm{dl}}$ values decreased in the presence 
TABLe 4: Electrochemical impedance, Tafel, and linear polarization resistance data at $308 \mathrm{~K}$.

\begin{tabular}{|c|c|c|c|c|c|c|c|}
\hline Name of inhibitor & $\begin{array}{c}\text { Inhibitor } \\
\text { concentration }\end{array}$ & $R_{\mathrm{ct}}\left(\Omega \mathrm{cm}^{2}\right)$ & $C_{\mathrm{dl}}\left(\mu \mathrm{F} \mathrm{cm}^{-2}\right)$ & $E(\%)$ & - $E_{\text {corr }}(\mathrm{mV}$ versus SCE) & $i_{\text {corr }}\left(\mathrm{mA} / \mathrm{cm}^{2}\right)$ & $E(\%)$ \\
\hline $1 \mathrm{M} \mathrm{HCl}$ & - & 8.5 & 68.9 & - & 446 & 1540.0 & - \\
\hline \multirow{3}{*}{ Syzygium cumini } & 240.0 & 97.1 & 67.6 & 91.2 & 443 & 165.0 & 89.2 \\
\hline & 300.0 & 117.5 & 56.1 & 92.7 & 462 & 98.0 & 93.5 \\
\hline & 600.0 & 238.5 & 53.7 & 96.4 & 469 & 60.0 & 96.0 \\
\hline \multirow{3}{*}{ Pongamia pinnata } & 300.0 & 129.5 & 39.6 & 92.9 & 461 & 84.0 & 94.0 \\
\hline & 350.0 & 150.6 & 38.7 & 93.5 & 482 & 77.0 & 95.0 \\
\hline & 400.0 & 239.8 & 35.7 & 96.5 & 471 & 49.0 & 97.0 \\
\hline \multirow{3}{*}{ Strychnos nuxvomica } & 250.0 & 130.3 & 52.0 & 93.5 & 461 & 132.0 & 91.4 \\
\hline & 300.0 & 159.9 & 47.1 & 94.7 & 463 & 97.0 & 93.7 \\
\hline & 350.0 & 263.9 & 43.3 & 96.7 & 494 & 27.5 & 98.2 \\
\hline
\end{tabular}

TABLE 5: Electrochemical impedance, Tafel, and linear polarization resistance data at $308 \mathrm{~K}$.

\begin{tabular}{|c|c|c|c|c|c|c|c|}
\hline Name of inhibitor & $\begin{array}{c}\text { Inhibitor } \\
\text { concentration }\end{array}$ & $R_{\mathrm{ct}}\left(\Omega \mathrm{cm}^{2}\right)$ & $C_{\mathrm{dl}}\left(\mu \mathrm{F} \mathrm{cm}^{-2}\right)$ & $E(\%)$ & $\begin{array}{c}-E_{\text {corr }}(\mathrm{mV} \\
\text { versus SCE })\end{array}$ & $i_{\text {corr }}\left(\mathrm{mA} / \mathrm{cm}^{2}\right)$ & $E(\%)$ \\
\hline $1 \mathrm{M} \mathrm{HCl}$ & - & 8.5 & 68.9 & - & 446 & 1540.0 & - \\
\hline \multirow{3}{*}{ Piper longum } & 240.0 & 213.2 .1 & 46.4 & 96.0 & 464 & 53.0 & 96.5 \\
\hline & 300.0 & 273.3 & 33.1 & 96.9 & 469 & 46.0 & 96.9 \\
\hline & 600.0 & 355.5 & 27.3 & 97.6 & 479 & 41.0 & 97.3 \\
\hline \multirow{3}{*}{ Moringa oleifera } & 200.0 & 215.0 & 43.0 & 96.0 & 503 & 59.0 & 96.1 \\
\hline & 250.0 & 324.5 & 41.4 & 97.3 & 472 & 38.0 & 97.5 \\
\hline & 300.0 & 644.9 & 32.4 & 98.6 & 493 & 28.0 & 98.1 \\
\hline \multirow{3}{*}{ Citrus aurantium } & 300.0 & 23.5 & 68.5 & 68.9 & 466 & 430.0 & 72.0 \\
\hline & 600.0 & 58.2 & 65.4 & 85.4 & 515 & 212.0 & 86.2 \\
\hline & 1200.0 & 65.2 & 56.3 & 87.0 & 464 & 160.0 & 89.6 \\
\hline
\end{tabular}

of all stem extract as in Table 6 and Figure 4. This may be due to the adsorption of these compounds at the metal/solution interface. Decrease in $C_{\mathrm{dl}}$ values, caused by a decrease in local dielectric constant and/or an increase in the thickness of the electrical double layer, suggests that the water molecules are replaced by inhibitor molecules. It was observed that the values of $I_{\text {corr }}$ decrease in the presence of inhibitors. The decrease in $I_{\text {corr }}$ values can be due to the adsorption of stems extract on the mild steel surface. The $b_{\mathrm{c}}$ and $b_{\mathrm{a}}$ values remained more or less identical in the absence and presence of stems extract studied, suggesting that the effect of inhibitors is not as large as to change the mechanism of corrosion.

All the studied plant extracts obtained from leaves, seeds, fruits, and stem showed good inhibition efficiency (>95\%) at their optimum concentrations for mild steel in $1 \mathrm{M} \mathrm{HCl}$. The optimum concentration is considered as a concentration beyond which increase in extract concentration showed no significant change in the inhibition efficiency. The good performance may be attributed to the synergism between the different compounds present in the extracts. Andrographis paniculata leaves extract showed 98\% inhibition efficiency due to the presence of delocalized $\pi$-electrons as compared to those of Strychnous nuxvomica seed extract which can be attributed to the presence of three methoxy groups attached to the benzene nucleus favoring its greater adsorption on the mild steel surface, thereby giving rise to very high inhibition efficiency (98.2\%) and Moringa oleifera fruit extract (98.1\%) due to the presence of imine $(\mathrm{C}=\mathrm{N})$ group, four $\mathrm{N}$ atoms and long alkyl chain. Also, the low inhibition efficiency of Bacopa monnieri as compared to Andrographis paniculata, Strychnous nuxvomica, and Moringa oleifera can be attributed to the presence of $\mathrm{O}$ atoms in its structure.

3.5. Mechanism of Corrosion Inhibition. In acidic solutions, transition of the metal/solution interface is attributed to the adsorption of the inhibitor molecules at the metal/solution interface, forming a protective film. The rate of adsorption is usually rapid, and hence, the reactive metal surface is shielded from the acid solutions [49]. The adsorption of an inhibitor depends on its chemical structure, its molecular size, the nature and charged surface of the metal, and distribution of charge over the whole inhibitor molecule. In fact, adsorption process can occur through the replacement of solvent molecules from the metal surface by ions and molecules accumulated near the metal/solution interface. Ions can accumulate at the metal/solution interface in excess of those required to balance the charge on the metal at the 
TABLE 6: Electrochemical impedance, Tafel, and linear polarization resistance data at $308 \mathrm{~K}$.

\begin{tabular}{|c|c|c|c|c|c|c|c|}
\hline Name of inhibitor & $\begin{array}{c}\text { Inhibitor } \\
\text { concentration }\end{array}$ & $\begin{array}{c}R_{\mathrm{ct}} \\
\left(\Omega \mathrm{cm}^{2}\right)\end{array}$ & $\begin{array}{c}C_{\mathrm{dl}} \\
\left(\mu \mathrm{F} \mathrm{cm}^{-2}\right) \\
\end{array}$ & $E(\%)$ & $\begin{array}{c}-E_{\text {corr }}(\mathrm{mV} \\
\text { versus SCE })\end{array}$ & $i_{\text {corr }}\left(\mathrm{mA} / \mathrm{cm}^{2}\right)$ & $E(\%)$ \\
\hline $1 \mathrm{M} \mathrm{HCl}$ & - & 8.5 & 68.9 & - & 446 & 1540.0 & - \\
\hline \multirow{3}{*}{ Terminalia arjuna } & 300.0 & 17.0 & 67.4 & 50.5 & 478 & 785.0 & 49.0 \\
\hline & 600.0 & 26.2 & 48.9 & 67.9 & 461 & 713.0 & 53.7 \\
\hline & 1200.0 & 75.9 & 38.8 & 88.9 & 469 & 220.0 & 85.7 \\
\hline \multirow{3}{*}{ Ficus religiosa } & 300.0 & 28.7 & 63.9 & 70.7 & 444 & 407.0 & 54.0 \\
\hline & 600.0 & 37.8 & 63.0 & 77.7 & 481 & 301.0 & 80.4 \\
\hline & 1200.0 & 75.6 & 37.6 & 88.8 & 464 & 190.0 & 87.6 \\
\hline \multirow{3}{*}{ Bacopa monnieri } & 240.0 & 41.9 & 53.5 & 79.9 & 464 & 518.0 & 66.3 \\
\hline & 300.0 & 74.2 & 44.2 & 88.6 & 486 & 218.0 & 85.8 \\
\hline & 600.0 & 175.2 & 39.4 & 95.2 & 489 & 75.0 & 95.1 \\
\hline
\end{tabular}

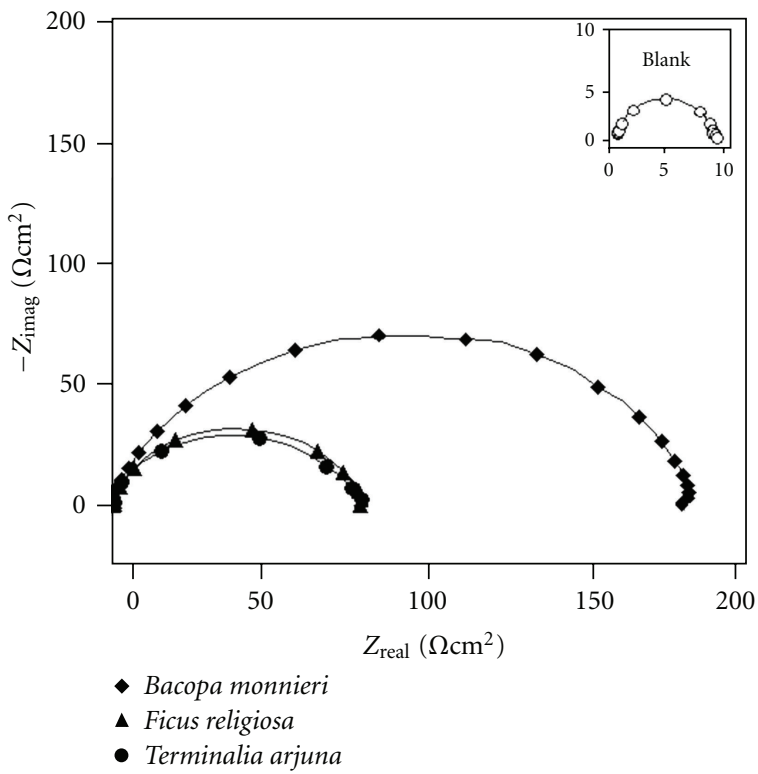

(a)

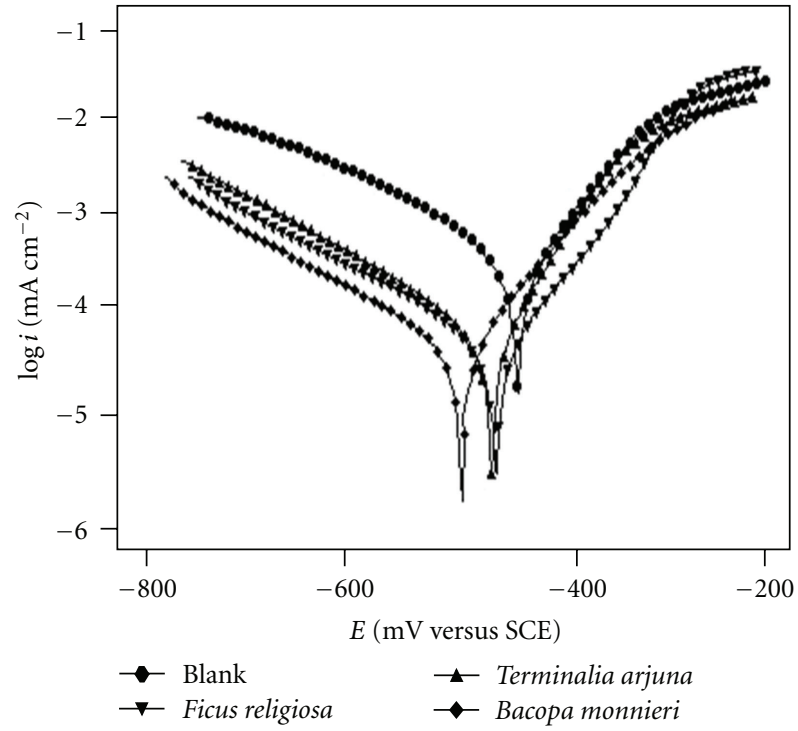

(b)

Figure 4: Nyquist plots and Tafel plots for mild steel in $1 \mathrm{M} \mathrm{HCl}$ in the absence and presence of different inhibitors at their optimum concentrations.

operating potential. These ions replace solvent molecules from the metal surface, and their centres reside at the inner Helmholtz plane. This phenomenon is termed specific adsorption, contact adsorption. The anions are adsorbed when the metal surface has an excess positive charge in an amount greater than that required to balance the charge corresponding to the applied potential. The exact nature of the interactions between a metal surface and an aromatic molecule depends on the relative coordinating strength towards the given metal of the particular groups present [50].

Generally, two modes of adsorption were considered. In one mode, the neutral molecules of leaves extract can be adsorbed on the surface of mild steel through the chemisorption mechanism, involving the displacement of water molecules from the mild steel surface and the sharing electrons between the heteroatoms and iron. The inhibitor molecules can also adsorb on the mild steel surface based on donor-acceptor interactions between $\pi$-electrons of the aromatic/heterocyclic ring and vacant d-orbitals of surface iron. In another mode, since it is well known that the steel surface bears the positive charge in acidic solutions [51], so it is difficult for the protonated leaves extract to approach the positively charged mild steel surface $\left(\mathrm{H}_{3} \mathrm{O}^{+} /\right.$metal interface) due to the electrostatic repulsion. Since chloride ions have a smaller degree of hydration, thus they could bring excess negative charges in the vicinity of the interface and favour more adsorption of the positively charged inhibitor molecules, the protonated leaves extract adsorbed through electrostatic interactions between the positively charged molecules and the negatively charged metal surface.

Since all the different parts of plant extract possess several heteroatoms containing active constituents, therefore there may be a synergism between the molecules accounting for the good inhibition efficiencies. 


\section{Conclusions}

(1) All the extracts studied showed good inhibition efficiency.

(2) Andrographis paniculata, Strychnous nuxvomica, and Moringa oleifera extracts showed inhibition efficiency above $98 \%$.

(3) All the extracts were found to be the mixed type of inhibitors.

(4) All the results obtained from EIS, LPR, and weight loss are in good agreement with each other.

\section{References}

[1] A. Y. El-Etre, M. Abdallah, and Z. E. El-Tantawy, "Corrosion inhibition of some metals using lawsonia extract," Corrosion Science, vol. 47, no. 2, pp. 385-395, 2005.

[2] E. A. Noor, "Temperature effects on the corrosion inhibition of mild steel in acidic solutions by aqueous extract of fenugreek leaves," International Journal of Electrochemcal Science, vol. 2, pp. 996-1017, 2007.

[3] A. Y. El-Etre, "Inhibition of acid corrosion of carbon steel using aqueous extract of olive leaves," Journal of Colloid and Interface Science, vol. 314, no. 2, pp. 578-583, 2007.

[4] P. B. Raja and M. G. Sethuraman, "Natural products as corrosion inhibitor for metals in corrosive media-A review," Materials Letters, vol. 62, no. 1, pp. 113-116, 2008.

[5] M. Shyamala and A. Arulanantham, "Eclipta alba as corrosion pickling inhibitor on mild steel in hydrochloric acid," Journal of Materials Science and Technology, vol. 25, no. 5, pp. 633-636, 2009.

[6] A. M. Abdel-Gaber, B. A. Abd-El-Nabey, and M. Saadawy, "The role of acid anion on the inhibition of the acidic corrosion of steel by lupine extract," Corrosion Science, vol. 51, no. 5, pp. 1038-1042, 2009.

[7] P. Bothi Raja and M. G. Sethuraman, "Solanum tuberosum as an inhibitor of mild steel corrosion in acid media," Iranian Journal of Chemistry and Chemical Engineering, vol. 28, no. 1, pp. 77-84, 2009.

[8] I. E. Uwah, P. C. Okafor, and V. E. Ebiekpe, "Inhibitive action of ethanol extracts from Nauclea latifolia on the corrosion of mild steel in $\mathrm{H}_{2} \mathrm{SO}_{4}$ solutions and their adsorption characteristics," Arabian Journal of Chemistry. In press.

[9] R. Saratha and R. Meenakshi, "Corrosion inhibitor-A plant extract," Der Pharma Chemica, vol. 2, pp. 287-294, 2010.

[10] A. Y. El-Etre, "Khillah extract as inhibitor for acid corrosion of SX 316 steel," Applied Surface Science, vol. 252, no. 24, pp. 8521-8525, 2006.

[11] M. J. Sanghvi, S. K. Shukla, A. N. Misra, M. R. Padh, and G. N. Mehta, "Inhibition of hydrochloric acid corrosion of mild steel by aid extracts of embilica officianalis, terminalia bellirica and terminalia chebula," Bulletin of Electrochemistry, vol. 13, no. 8-9, pp. 358-361, 1997.

[12] E. E. Ebenso, J. Udofot, J. Ekpe, and U. J. Ibok, "Studies on the inhibition of mild steel corrosion by some plant extracts in acidic medium," Discovery and Innovation, vol. 10, no. 1-2, pp. 52-59, 1998.

[13] A. Bouyanzer, B. Hammouti, and L. Majidi, "Pennyroyal oil from Mentha pulegium as corrosion inhibitor for steel in $1 \mathrm{M}$ HCl," Materials Letters, vol. 60, no. 23, pp. 2840-2843, 2006.
[14] L. R. Chauhan and G. Gunasekaran, "Corrosion inhibition of mild steel by plant extract in dilute $\mathrm{HCl}$ medium," Corrosion Science, vol. 49, no. 3, pp. 1143-1161, 2007.

[15] E. Khamis and N. Alandis, "Herbs as new type of green inhibitors for acidic corrosion of steel," Materialwissenschaft und Werkstofftechnik, vol. 33, no. 9, pp. 550-554, 2002.

[16] H. H. Rehan, "Corrosion control by water-soluble extracts from leaves of economic plants," Materialwissenschaft und Werkstofftechnik, vol. 34, no. 2, pp. 232-237, 2003.

[17] M. G. Sethuraman and P. B. Raja, "Corrosion inhibition of mild steel by Datura metel in acidic medium," Pigment and Resin Technology, vol. 34, no. 6, pp. 327-331, 2005.

[18] R. A. L. Sathiyanathan, M. M. Essa, S. Maruthamuthu, M. Selvanayagam, and N. Palaniswamy, "Inhibitory effect of Ricinus communis (Castor-oil plant) leaf extract on corrosion of mild steel in low chloride medium," Journal of the Indian Chemical Society, vol. 82, no. 4, pp. 357-359, 2005.

[19] E. Chaieb, A. Bouyanzer, B. Hammouti, and M. Benkaddour, "Inhibition of the corrosion of steel in $1 \mathrm{M} \mathrm{HCl}$ by eugenol derivatives," Applied Surface Science, vol. 246, no. 1-3, pp. 199206, 2005.

[20] P. C. Okafor and E. E. Ebenso, "Inhibitive action of Carica papaya extracts on the corrosion of mild steel in acidic media and their adsorption characteristics," Pigment and Resin Technology, vol. 36, no. 3, pp. 134-140, 2007.

[21] J. Buchweishaija and G. S. Mhinzi, "Natural products as a source of environmentally friendly corrosion inhibitors: the case of gum exudate from Acacia seyal var. seyal," Portugaliae Electrochimica Acta, vol. 26, no. 3, pp. 257-265, 2008.

[22] P. B. Raja and M. G. Sethuraman, "Inhibition of corrosion of mild steel in sulphuric acid medium by Calotropis procera," Pigment and Resin Technology, vol. 38, no. 1, pp. 33-37, 2009.

[23] M. Shyamala and A. Arulanantham, "Corrosion inhibition effect of centella asiatica (Vallarai) on mild steel in hydrochloric acid," Asian Journal of Chemistry, vol. 21, no. 8, pp. 61026110, 2009.

[24] C. Anca, M. Ioana, D. I. Vaireanu, L. Iosif, L. Carmen, and C. Simona, "Estimation of inhibition efficiency for carbon steel corrosion in acid media by using natural plant extracts," Revista de Chimie, vol. 60, no. 11, pp. 1175-1180, 2009.

[25] P. C. Okafor, I. E. Uwah, O. O. Ekerenam, and U. J. Ekpe, "Combretum bracteosum extracts as eco-friendly corrosion inhibitor for mild steel in acidic medium," Pigment and Resin Technology, vol. 38, no. 4, pp. 236-241, 2009.

[26] P. C. Okafor, M. E. Ikpi, I. E. Uwah, E. E. Ebenso, U. J. Ekpe, and S. A. Umoren, "Inhibitory action of Phyllanthus amarus extracts on the corrosion of mild steel in acidic media," Corrosion Science, vol. 50, no. 8, pp. 2310-2317, 2008.

[27] P. C. Okafor, E. E. Ebenso, and U. J. Ekpe, "Azadirachta indica extracts as corrosion inhibitor for mild steel in acid medium," International Journal of Electrochemical Science, vol. 5, no. 7, pp. 978-993, 2010.

[28] N. O. Eddy and E. E. Ebenso, "Adsorption and inhibitive properties of ethanol extracts of Musa sapientum peels as a green corrosion inhibitor for mild steel in $\mathrm{H}_{2} \mathrm{SO}_{4}$," African Journal of Pure and Applied Chemistry, vol. 2, pp. 046-054, 2008.

[29] A. Sharmila, A. A. Prema, and P. A. Sahayaraj, "Influence of Murraya koenigii (curry leaves) extract on the corrosion inhibition of carbon steel in HCL solution," Rasayan Journal of Chemistry, vol. 3, no. 1, pp. 74-81, 2010.

[30] A. M. Al-Turkustani, S. T. Arab, and L. S. S. Al-Qarni, "Medicago Sative plant as safe inhibitor on the corrosion of steel in $2.0 \mathrm{M} \mathrm{H}_{2} \mathrm{SO}_{4}$ solution," Journal of Saudi Chemical Society, vol. 15, no. 1, pp. 73-82, 2011. 
[31] M. Lebrini, F. Robert, A. Lecante, and C. Roos, "Corrosion inhibition of C38 steel in $1 \mathrm{M}$ hydrochloric acid medium by alkaloids extract from Oxandra asbeckii plant," Corrosion Science, vol. 53, no. 2, pp. 687-695, 2011.

[32] M. Shyamala and P. K. Kasthuri, "The inhibitory action of the extracts of Adathoda vasica, Eclipta alba, and Centella asiatica on the corrosion of mild steel in hydrochloric acidMedium: a comparative study," International Journal of Corrosion, vol. 2012, Article ID 852827, 13 pages, 2012.

[33] M. Shyamala and P. K. Kasthuri, "A comparative study of the inhibitory effect of the extracts of Ocimum sanctum, Aegle marmelos, and Solanum trilobatum on the corrosion of mild steel in hydrochloric acid medium," International Journal of Corrosion, vol. 2011, Article ID 129647, 11 pages, 2011.

[34] M. Lebrini, F. Robert, and C. Roos, "Inhibition effect of alkaloids extract from Annona squamosa plant on the corrosion of C38 steel in normal hydrochloric acid medium," International Journal of Electrochemical Science, vol. 5, no. 11, pp. 1698$1712,2010$.

[35] N. O. Eddy and A. O. Odiongenyi, "Corrosion inhibition and adsorption properties of ethanol extract of Heinsia crinata on mild steel in $\mathrm{H}_{2} \mathrm{SO}_{4}$," Pigment and Resin Technology, vol. 39, no. 5, pp. 288-295, 2010.

[36] E. E. Oguzie, C. K. Enenebeaku, C. O. Akalezi, S. C. Okoro, A. A. Ayuk, and E. N. Ejike, "Adsorption and corrosion-inhibiting effect of Dacryodis edulis extract on low-carbon-steel corrosion in acidic media," Journal of Colloid and Interface Science, vol. 349, no. 1, pp. 283-292, 2010.

[37] R. Saratha and V. G. Vasudha, "Emblica Officinalis (Indian Gooseberry) leaves extract as corrosion inhibitor for mild steel in 1N HCL medium," E-Journal of Chemistry, vol. 7, no. 3, pp. 677-684, 2010.

[38] S. Subhashini, R. Rajalakshmi, A. Prithiba, and A. Mathina, "Corrosion mitigating effect of Cyamopsis Tetragonaloba seed extract on mild steel in acid medium," E-Journal of Chemistry, vol. 7, no. 4, pp. 1133-1137, 2010.

[39] M. A. Quraishi, "Investigation of some green compounds as corrosion and scale inhibitors for cooling systems," Corrosion, vol. 55, no. 5, pp. 493-497, 1999.

[40] A. Minhaj, P. A. Saini, M. A. Quraishi, and I. H. Farooqi, "A study of natural compounds as corrosion inhibitors for industrial cooling systems," Corrosion Prevention and Control, vol. 46, no. 2, pp. 32-38, 1999.

[41] I. H. Farooqi, M. A. Quraishi, and P. A. Saini, "Corrosion prevention of mild steel in $3 \% \mathrm{NaCl}$ water by some naturallyoccurring substances," Corrosion Prevention and Control, vol. 46, no. 4, pp. 93-96, 1999.

[42] I. H. Farooqi, M. A. Nasir, and M. A. Quraishi, "Environmentally-friendly inhibitor formulations for industrial cooling systems," Corrosion Prevention and Control, vol. 44, no. 5, pp. 129-134, 1997.

[43] M. A. Quraishi, A. Singh, V. K. Singh, D. K. Yadav, and A. K. Singh, "Green approach to corrosion inhibition of mild steel in hydrochloric acid and sulphuric acid solutions by the extract of Murraya koenigii leaves," Materials Chemistry and Physics, vol. 122, no. 1, pp. 114-122, 2010.

[44] A. Singh, I. Ahamad, V. K. Singh, and M. A. Quraishi, "Inhibition effect of environmentally benign Karanj (Pongamia pinnata) seed extract on corrosion of mild steel in hydrochloric acid solution," Journal of Solid State Electrochemistry, vol. 15, pp. 1087-1097, 2011.

[45] A. Singh, V. K. Singh, and M. A. Quraishi, "Aqueous extract of Kalmegh (Andrographis paniculata) leaves as green inhibitor for mild steel in hydrochloric acid solution," International
Journal of Corrosion, vol. 2010, Article ID 275983, 10 pages, 2010.

[46] A. Singh, V. K. Singh, and M. A. Quraishi, "Effect of fruit extracts of some environmentally benign green corrosion inhibitors on corrosion of mild steel in hydrochloric acid solution," Journal of Materials and Environmental Science, vol. 1, no. 3, pp. 162-174, 2010.

[47] A. Singh, V. K. Singh, and M. A. Quraishi, "Inhibition effect of environmentally benign Kuchla (Strychnos nuxvomica) seed extract on corrosion of mild steel in hydrochloric acid solution," Rasayan Journal of Chemistry, vol. 3, pp. 811-824, 2010.

[48] A. Singh, I. Ahamad, D. K. Yadav, V. K. Singh, and M. A. Quraishi, "The effect of environmentally benign fruit extract of Shahjan (Moringa oleifera) on the corrosion of mild steel in hydrochloric acid solution," Chemical Engineering Communications, vol. 199, no. 1, pp. 63-77, 2012.

[49] C. Y. Chao, L. F. Lin, and D. D. Macdonald, "A point defect model for anodic passive films," Journal of the Electrochemical Society, vol. 128, no. 6, pp. 1187-1194, 1981.

[50] I. M. Ritchie, S. Bailey, and R. Woods, "Metal-solution interface," Advances in Colloid and Interface Science, vol. 80, no. 3, pp. 183-231, 1999.

[51] G. N. Mu, T. P. Zhao, M. Liu, and T. Gu, "Effect of metallic cations on corrosion inhibition of an anionic surfactant for mild steel," Corrosion, vol. 52, no. 11, pp. 853-856, 1996. 

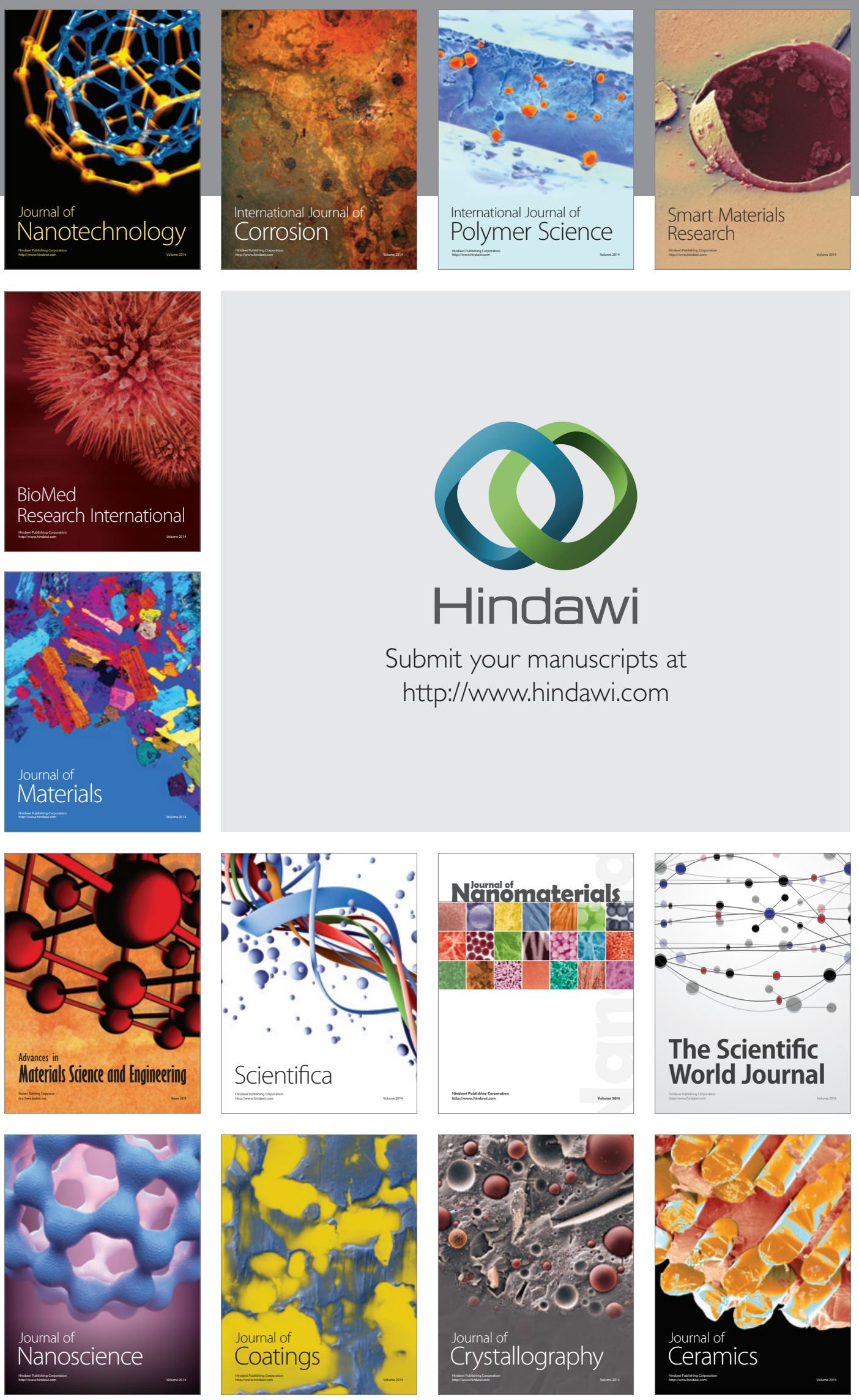

The Scientific World Journal

Submit your manuscripts at

http://www.hindawi.com

\section{World Journal}

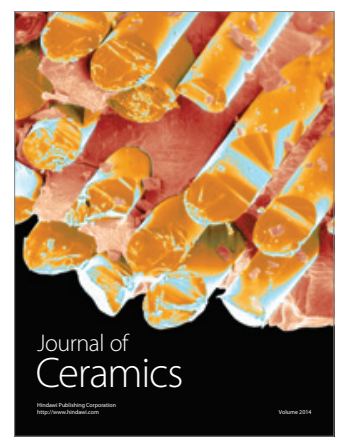

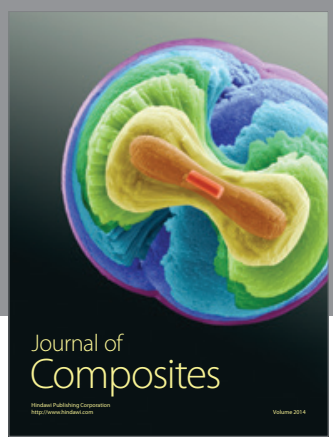
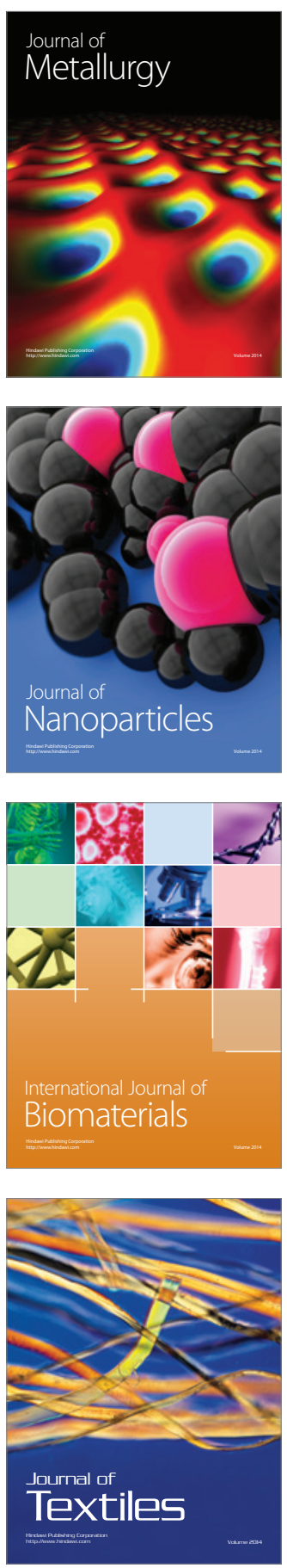